\title{
Appropriation and Architecture: Mary Magdalene in Vézelay
}

Mariëtte VerhoEVEN

In the Middle Ages thousands of pilgrims visited the church on the top of the hill in Vézelay because of the presence of the relics of Mary Magdalene. Mary Magdalene is an example of a saint whose cult was appropriated to a location that originally had no connection whatsoever with that saint. I engaged with the phenomenon of appropriated saints during my $\mathrm{PhD}$ research on the monuments and memory of Ravenna, which was supervised by Sible de Blaauw. ${ }^{1}$ According to the Passio SS. Martyrum Gervasii et Protasii (end fifth, beginning sixth century), St Vitalis, whose remains had been excavated by $\mathrm{St}$ Ambrose in Bologna, suffered his martyrdom in Ravenna where his grave became a place of veneration. ${ }^{2}$ Nowadays the magnificent Church of S. Vitale in Ravenna still testifies to the successful appropriation of the Bolognese saint. Other famous examples of appropriated saints are $\mathrm{St}$ Mark in Venice (originally from Alexandria), St Nicholas in Bari (originally from Myra), and St James in Santiago de Compostela (originally from Jerusalem). In all these cases the ingredients for a successful appropriation include the translation of relics, preferably the complete body, a written confirmation in the form of a passio or translatio, and the disposition of the relics in a church building that is dedicated to the saint. The church building not only confirms the appropriation by means of its function as relic shrine but also keeps this memory alive while practically erasing the connection of the saint with his or her origins. As well as the case of S. Vitale, the churches of St Mark in Venice, of St Nicholas in Bari and of St James in Santiago de Compostela still testify to the continuity of the relocated cult and their function as places of pilgrimage.

In Vézelay, however, things developed differently. According to the Liber Sancti Jacobi, the pilgrim's guide to Santiago de Compostela, the most worthy remains of the Blessed Mary Magdalene had to be rightly worshipped in Vézelay, 'where they rest up to this day in a much honoured tomb'. The Liber Sancti Jacobi was written around the middle of the twelfth century, when the cult of Mary Magdalene in Vézelay was at its height. By the end of the thirteenth century, however, Saint-Maximin-de-Provence successfully claimed the possession of the body of Mary Magdalene and the once so popular pilgrimage to Vézelay came to a halt. In this paper I will focus on the development of the cult of Mary Magdalene in relation to its architectural framework in Vézelay. What was the material setting in which the relics were placed and did the process of appropriation and its material manifestation contribute to the loss of the cult in the thirteenth century? And how did the relics of this biblical saint come to Vézelay in the first place?

\section{Origins and Development of the Cult}

The earliest official recognition of the cult of Mary Magdalene at Vézelay was a privilege of Pope Leo IX, dated 27 April Io5o. It was addressed to Abbot Gaufredus and it mentions the dedication of the monastery of Vézelay to Jesus Christ, his mother Mary, the apostles Peter and Paul and Mary Magdalene. ${ }^{4}$ In I0 8 Pope Stephan X proclaimed that Mary Magdalene rested in the monastery of Vézelay, implying that Vézelay possessed the body of the female saint. ${ }^{5} \mathrm{Be}-$ sides these official documents, Mary Magdalene figures in narratives describing miracles that took place in Vézelay. These miracle accounts have survived in different versions but all versions include the story of a soldier from the Auvergne who had been freed from imprisonment through the intervention of Mary Magdalene and who suspended his chains in front of her grave at the monastery of Vézelay. ${ }^{6}$ The most 


\section{Mariëtte Verhoeven}

elaborate version of these miracle accounts mentions that Abbot Gaufredus found iron chains in the monastery and had a balustrade made from them, setting it up around the altar.?

Prisoners and chains also figure in narratives relating to Conques, Saint-Léonard-de-Noblat and Saintes, all of them, like Vézelay places of pilgrimage on the way to Santiago de Compostela; Conques on the route starting from Le Puy, Saint-Léonard on the route from Vézelay and Saintes on the one from Paris and Tours. The Liber miraculorum of St Foy, the saint whose relics were venerated in Conques, contains an eyewitness account of Bernard of Angers who visited the church in Conques in the early eleventh century. Bernard describes the abundance of iron grillwork made from chains and fetters brought to Sainte-Foy as offerings of thanks from prisoners whom she had freed. ${ }^{8}$ The author of the already mentioned Liber Sancti Jacobi reports about St Leonard that,

his extraordinarily powerful virtues have delivered from prison countless thousands of captives; their iron chains, more barbarous than what one can possibly recount, joined together by the thousands, have been appended in testimony of such great miracles all around his basilica, to the right and to the left, inside and outside. ${ }^{9}$

With regard to Saintes, the author of the Liber Sancti Jacobi claims that he found the passio of Saintes's bishop and martyr St Eutropius, which was written in Greek by his companion Dionysius, in a Greek school at Constantinople, and translated it into Latin. According to this passio, in the church that the Christians erected in his honour over the saintly body of Eutropius, iron chains and handcuffs were to be found hanging, along with various other iron instruments from which Eutropius had freed those enchained in them. ${ }^{\text {Io }}$

At Conques in the extreme left-hand corner of the tympanum of the Romanesque church, an iron fetter hanging from a beam can be seen behind the kneeling figure of St Foy, and the iron grill work, supposedly made from chains and fetters as described by Bernard of Angers, still stands between the columns that separate the choir from the ambulatory.

Pilgrims badges originating from SaintLéonard-de-Noblat attest that chains became St Leonard's fixed attribute in his function of patron saint of prisoners. ${ }^{I I}$

In the case of Vézelay, apart from the miracle accounts, there is no material evidence of the veneration of Mary Magdalene in her role as intervener in the liberation of prisoners. The suspension of chains in front of her grave and the balustrade that Abbot Gaufredus had made from them seems to be an topos that was borrowed from the comparable miracle accounts that circulated during the eleventh century, rather than a description of the actual situation in Vézelay, as has been suggested. ${ }^{\mathrm{I}}$ It is not possible to determine whether the Vézelay miracle accounts led to the official recognition of a connection between Mary Magdalene and Vézelay in I050 and 1058 or if these accounts proceeded from it. ${ }^{13}$ Mary Magdalene was venerated before I050 in other places in France and Vézelay may have been one of them. ${ }^{14}$ It also seems logical that the official recognition of the presence of the relics of Mary Magdalene in Vézelay was the confirmation of some kind of cult that already existed, but there is no way to be certain.

As for the explanation of how the relics of Mary Magdalene came from Palestine to Vézelay, the author of the miracle accounts responds to pilgrims who doubted the presence of the relics in Vézelay, "that anything is possible to God'. 's However, the Gestes des évêques de Cambrai mention Badilon, Abbot of Leuze, as the agent who brought the body of Mary Magdalene from Jerusalem into Burgundy, into the town of Vézelay. ${ }^{16}$ Around the middle of the eleventh century two different accounts arise of how the relics of Mary Magdalen came to Vézelay from Provence. ${ }^{17}$ According to one version, Adelelmus (Aleaume), brother of Abbot Eudes of Vézelay, brought the relics from Provence around $882-84 .{ }^{18}$ A second version relates how the monk Badilon brought the relics from Aix-en-Provence to Vézelay by order of Gerard of Roussillon. ${ }^{19}$ These accounts not only give an explanation for the presence of the relics of Mary Magdalene in Vézelay but also claim 
that the translation from Provence occurred in the ninth century. Moreover, the antedating ties in with the building history of the monastery and church.

In 858-59, Gerard of Roussillon and his wife Bertha founded a nunnery in Saint-Père-sousVézelay. ${ }^{20}$ This nunnery was destroyed during Norman raids and refounded c. 877 as a monastery and church on top of the hill in Vézelay. ${ }^{21}$ It was, however, not dedicated to Mary Magdalene but to Jesus Christ, the Virgin Mary and the apostles Peter and Paul. ${ }^{22}$ The first mention of Mary Magdalene in relation to the church in Vézelay dates, as we have seen, from the eleventh century. But, according to the Translatio SS. Eusebii et Pontiani, a source that can be dated back to Carolingian times, Vézelay was in the possession of relics: the author relates how Gerard of Roussillon and his wife Bertha acquired the relics of Eusebius and Pontianus from the pope in Rome. On their way back to Vézelay, they also obtained relics of Sts Andeolus and Hostianus in Viviers. ${ }^{23}$ According to tradition the relics of Eusebius and Hostianus ended up in Pothières, and those of Andeolus and Pontianus in Vézelay. ${ }^{24}$ The ninth-century Translatio SS. Eusebii et Pontiani was possibly the inspiration for the eleventh-century accounts explaining how the relics of Mary Magdalene came to Vézelay from Provence. The latter were probably also inspired by the furta sacra account of Conques, which treats of the secret theft of the body of St Foy in Agen and its translation to Conques in the ninth century. ${ }^{25}$

\section{The Architectural Setting}

We have no information about the form of the ninth-century church that was built on top of the hill in Vézelay by Gerard of Roussillon and his wife Bertha. The church was rededicated in IIO4 under Abbot Artaud (IO96-IIO6), after a complete rebuilding of the choir part. ${ }^{26}$ If indeed no major changes took place between the initial building period in the ninth century and Artaud's reconstruction, this means that the church was not designed for housing the relics of Mary Magdalene. A vita of the saint dating from before II 80-90 mentions that Abbot Gaufredus wanted to demolish the exiguam cryptam in which the body of Mary Magdalene was kept, in order to replace it with a more important and richer grave. ${ }^{27}$ Francis Salet concluded in 1948 that this 'diminutive crypt' referred to a still existing confessio in the ninth-century crypt. ${ }^{28}$ Recent archeological research has shown, however, that the eastern termination of the ninth-century church was located further west than the western wall of the confessio in the existing crypt. ${ }^{29}$ Christian Sapin therefore concludes that the exiguam cryptam mentioned in the twelfth-century vita refers to a setting, possibly a crypt confessio or small grave chamber in the Carolingian choir that terminated in a straight wall..$^{30}$ It was only with the reconstruction of the choir under $\mathrm{Ab}-$ bot Artaud (I096-IIO6) that a hall crypt with lateral accesses, a common type in the eleventh century, was constructed, now with a confessio in the form of a deep barrel vaulted niche at the western end, and a fenestella in both side walls of the niche. ${ }^{3 \mathrm{I}}$ This new setting was most likely designed to provide a worthier resting place for the relics of Mary Magdalene.

That the relics of Mary Magdalene probably had been put from the beginning in a relatively small sepulchre, of which the form is unknown, also becomes clear from the eleventh-century translation account relating how the monk Badilon brought the relics from Aixen-Provence to Vézelay by order of Gerard of Roussillon (see above).32 The author describes how Badilon and his companions, before they arrived in Vézelay and before they brought the body of Mary Magdalene into the church, 'separated the longer bones of the body and put them alongside the rest of the body so that they could fit it into a smaller place'. The author gives no further details or description of the sepulchre or the place in which it was put. This contrasts with his detailed description of the tomb of Mary Magdalene in Aix-en-Provence in which Badilon had discovered the whole body: 'The carving of this sepulchre revealed her whose bodily remains were preserved within it. Covering its surface was a piece of work, rather like bas-relief, [showing] how Mary Magdalene [...]', and then the author continues with a 


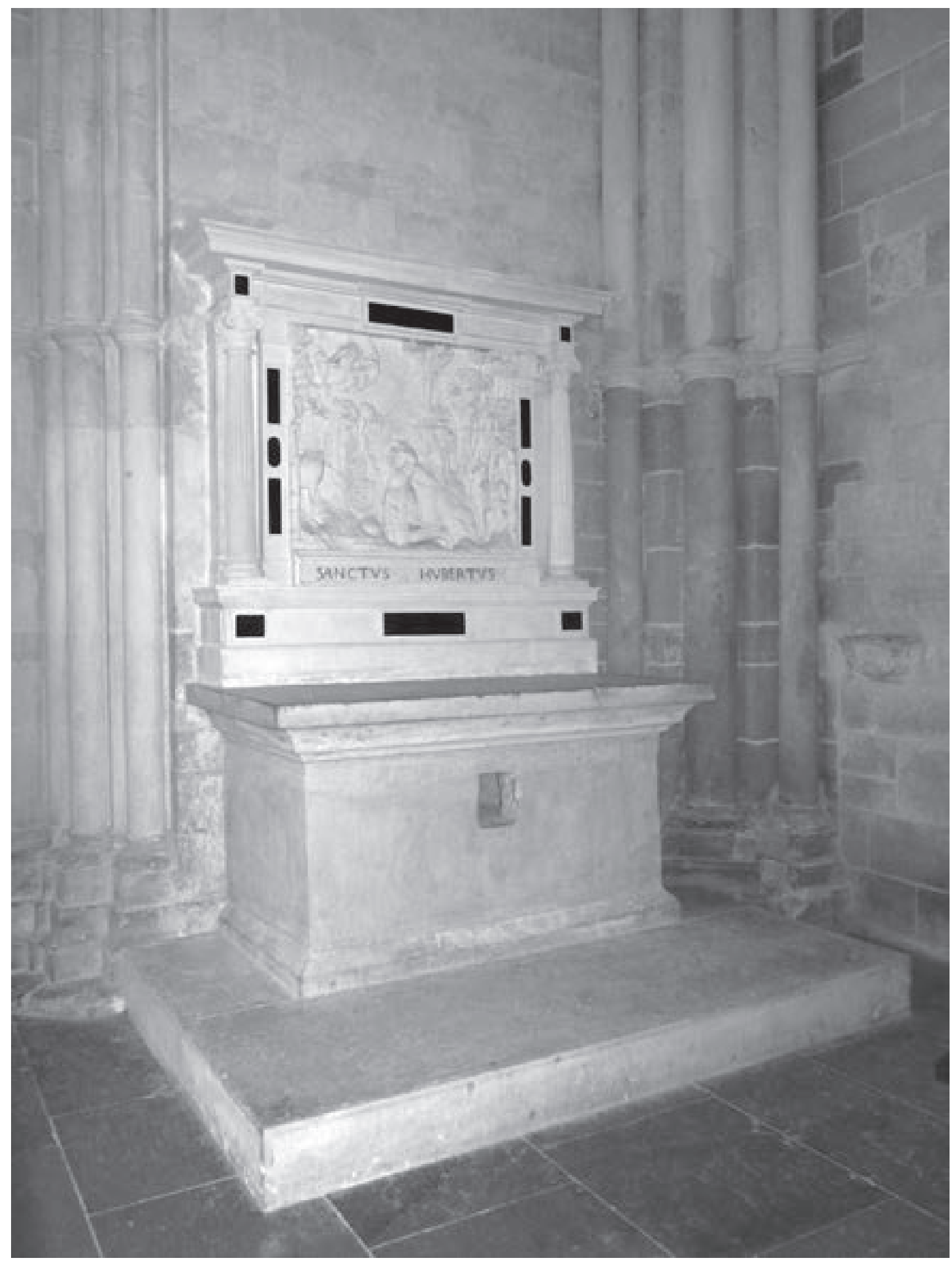

Fig. I. Vézelay, Church of St Mary Magdalene, altar in the south transept of the church. Photo by the author. 
description of events from her life which were depicted on the tomb. ${ }^{33}$

On 2I July II2O, the eve of the feast day of Mary Magdalene, the church in Vézelay was devastated by a large fire after which the construction of the present nave started under $\mathrm{Ab}$ bot Renaud (IIO6-28). ${ }^{34}$ In II 32 the so-called 'Church of the Pilgrims' was dedicated in the presence of Pope Innocent II. ${ }^{35}$ By I I 40 the main body of the church was certainly completed, the narthex and façade some io years later. ${ }^{36}$ After another fire in II65, a new Gothic choir and transept was built..$^{37}$ Hugh of Poitiers, author of the Vézelay or Major Chronicle, written shortly after 1165 , describes the fire in the church and states that

In the vault above the tomb of God's blessed lover Mary Magdalene such a blaze accidentally broke out that even the supports above it, which the French call beams, were burnt. But the wooden image of Mary, blessed mother of God, which stood on the floor of the vault, was not harmed by the fire at all, although it was a little blackened. ${ }^{38}$

This text passage is the oldest surviving testimony of the crypt being the location where the relics of Magdalene were disposed and it confirms that in II65 the relics were still kept in the crypt. ${ }^{39}$ We are also told that, besides the tomb of Mary Magdalene, a wooden statue of the Virgin Mary stood on the floor of the crypt. In fact, the author of the chronicle pays much more attention to the statue of the Virgin Mary and the relics it contained - among which were bones of the apostles Peter, Paul, Andrew, James and Bartholomew - than to the tomb of Mary Magdalene. The disposition of tomb and statue in the crypt is unknown. The fact that the wooden statue miraculously survived the fire could mean that it stood in the confessio niche while the tomb of Mary Magdalene stood in the central space of the crypt where wooden beams caught fire. An opposite arrangement, however, is also possible. ${ }^{40}$ As for the tomb, Francis Salet suggested that the main part of the altar that now stands in the south transept of the church (Fig. I) consists of the tomb with fenestella in which Gerard of Roussillon disposed the relics of Mary Magda- lene and which was placed in the confessio niche of the crypt in the ninth century. ${ }^{41}$ As has been shown, however, the translation of the relics of Mary Magdalene from Provence was an eleventh-century invention and the confessio niche likewise dates from the end of the eleventh or the beginning of the twelfth century. Christian Sapin suggests a form for the tomb in the crypt that is comparable with that of St Magnance; a freestanding sculptured sarcophagus (Fig. 2). ${ }^{42}$ Sapin refers, without further specification, to fragments in the museum that could have been part of such a tomb. It is likely that he refers to three fragments in 'Autun style' in the Musée de l'Euvre Viollet-le-Duc in Vézelay, which were found during the demolition in the nineteenth century of both the altar and pavement of the first chapel to the south of the choir. ${ }^{43}$ The subject of the carvings on these fragments is unknown but the standing figure on the frontonlike piece can be identified as a soldier (Fig. 3). It is therefore tempting to suppose that it is the soldier from the Auvergne who was freed from imprisonment through the intervention of Mary Magdalene and who suspended his chains in front of her grave at the monastery of Vézelay. ${ }^{44}$ This would have been an appropriate subject for the tomb of Mary Magdalene or for the altar of the Romanesque choir to which the fragments (dated II2O-40) also have been attributed. ${ }^{45}$

After the fire of II65, not only were a new Gothic choir and transept constructed but the crypt was also enlarged to a size that corresponded with the new choir. ${ }^{46}$ Only the western wall of the Romanesque crypt, including the confessio, remained; the fenestellae, however, were now walled up. This made it impossible to see into the confessio niche from the church. To see the relics one had to descend the lateral stairs which gave entrance to the crypt. ${ }^{47}$ The Gothic crypt consisted of three naves divided into six groin vaulted bays. In order to realize the new crypt, the rocky bottom was excavated, leaving a part of it visible, probably to create the impression of a cave.

In the eleventh and twelfth centuries we see an increase in the phenomenon of elevatio, the translation of relics from the crypt to the main altar or to a location that is connected with it. ${ }^{48}$ 


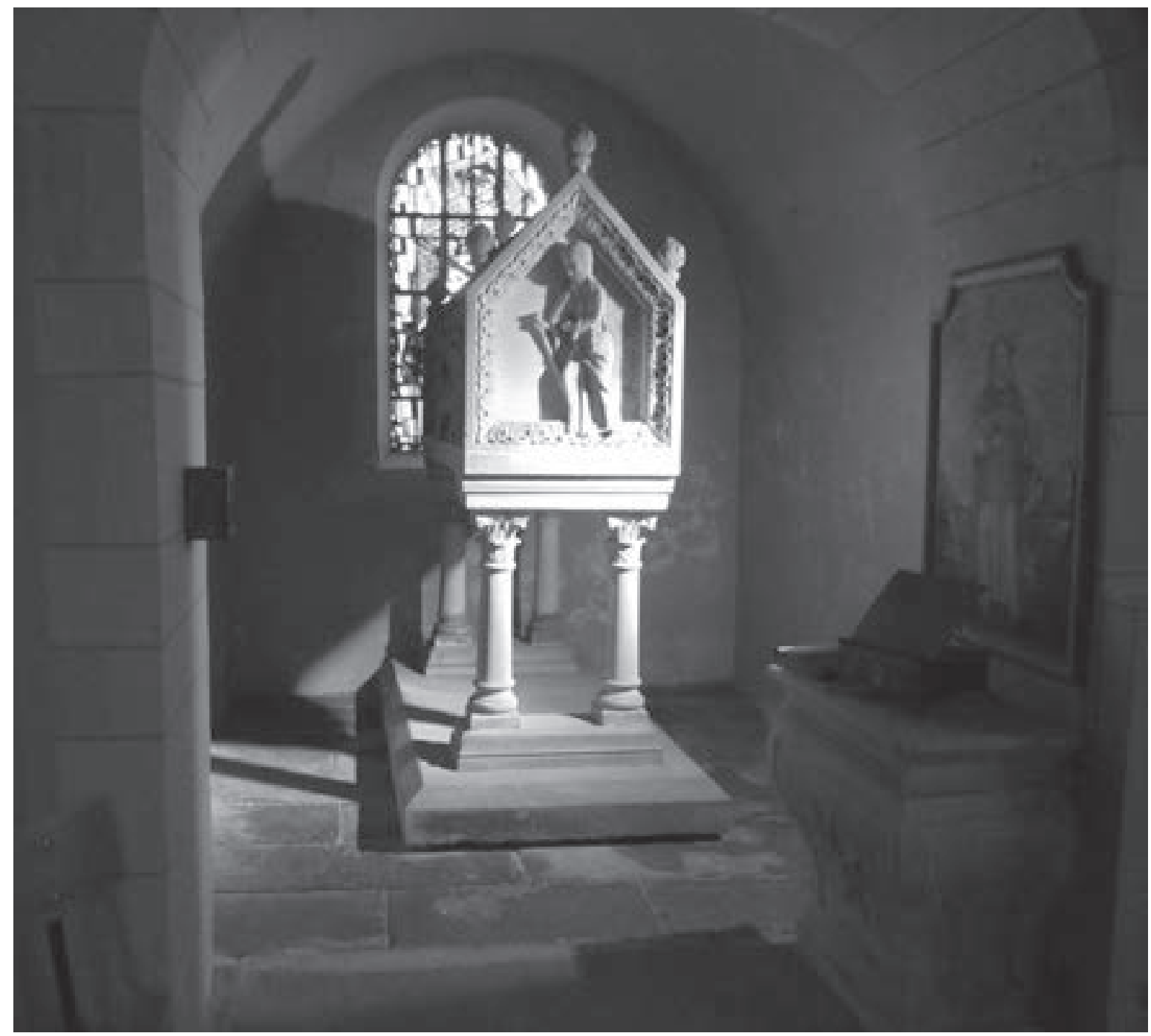

Fig. 2. Sainte-Magnance, sarcophagus of St Magnance in the church named after the saint. Photo by the author.

The rebuilding of the church at Saint-Denis in the IIzos under Abbot Suger included a translation of the relics of the patron saint and his companions Rusticus and Eleutherius from the Carolingian crypt to the new upper choir without abandoning the space of the crypt. ${ }^{49}$

At Autun the relics of St Lazarus were disposed in the Cathedral of St Nazarius. Around the middle of the twelfth century the relics were transferred to a church dedicated to the saint, the construction of which had started in III9. The relics were placed in the choir in a free-standing monumental marble mausoleum, measuring $5.50 \times 2.20$ (width of the inner space) $\times 6 \mathrm{~m} .^{50}$ The setting at Autun was that of a church enclosing a miniature church which in its turn contained a tomb with the relics of St Lazarus and a staging of his resurrection, with statues of Christ, St Peter, St Andrew, the Virgin Mary, and Mary Magdalene. A reconstruction of this setting and the remains of the marble mausoleum, including the statues of St Andrew, the Virgin Mary, and Mary Magdalene, are now exhibited at the Rolin Museum in Autun (Fig. 4).

For nearby Saulieu, also, it is attested that in III the relics of St Andoche and other saints were elevated from the crypt to the choir by 


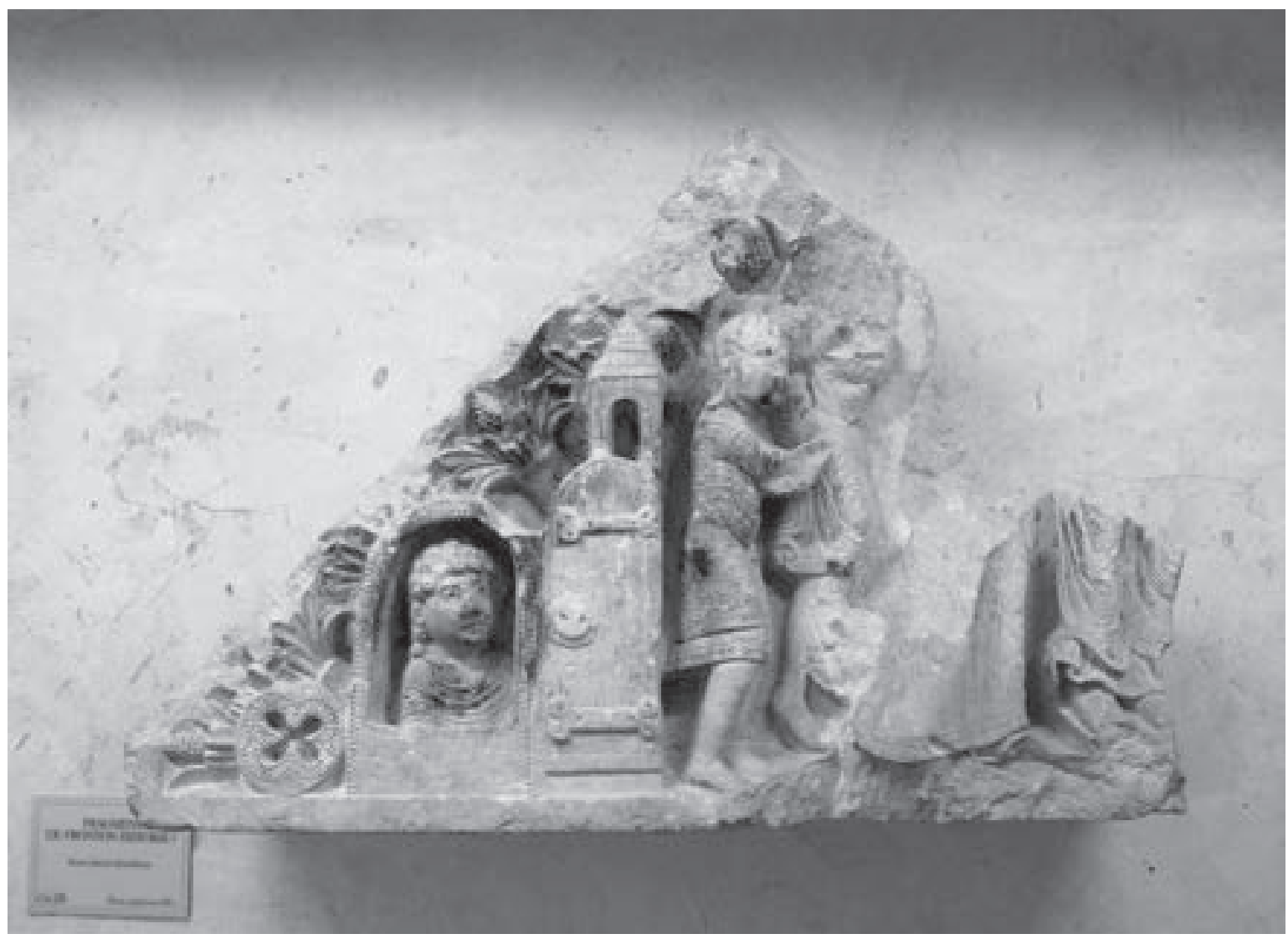

Fig. 3. Fragment of a fronton-like piece of sculpture (c. II2O-40) found during the demolition in the nineteenth century of both the altar and pavement of the first chapel to the south of the choir of the Church of St Mary Magdalene in Vézelay. Vézelay: Musée de l'CEuvre Viollet-le-Duc. Photo by the author.

Pope Calixtus..$^{\text {I }}$ For Vézelay, however, there is no evidence that either the rebuilding of the choir under Abbot Artaud at the beginning of the eleventh century, or the reconstruction of choir, transept and crypt after the fire of II65, involved an elevatio of the relics of Mary Magdalene to the upper church. ${ }^{52}$ If indeed the relics were not transferred to the upper choir, and if they could only be seen if one descended the stairs of the crypt, what other references to the presence of, and the dedication to, Mary Magdalene where there for a pilgrim visiting the church in the twelfth and thirteenth centuries? Not many, so it seems. Remarkably enough, the female saint does not appear in any of the scenes of the sculptural programme for which the church became famous: the capitals of the nave and the tympanums above the entrances to the nave dating from II $20-40.53$ Only in the west façade, which was constructed together with the narthex $c$. II40-50, does the lintel beneath the central tympanum show scenes from the lives of Mary Magdalene and Lazarus. Both tympanum and lintel were removed in I85I by Viollet-le-Duc and placed against the south side of the church. Because of weathering, the carvings on the lintel are hardly recognizable but two of them have been identified as the Resurrection of Lazarus and Mary Magdalene kneeling in front of Jesus Christ. ${ }^{54}$

Around I240-50 the upper part of the façade was decorated with a large window and gable with monumental statues (Fig. 5).55 A statue of Mary Magdalene stands in the apex of the gable, for the viewer to the right of the remains of the figure of Christ seated. To the left of Christ appears the figure of the Virgin Mary. Both of them are mentioned in the original dedication 


\section{Mariëtte Verhoeven}

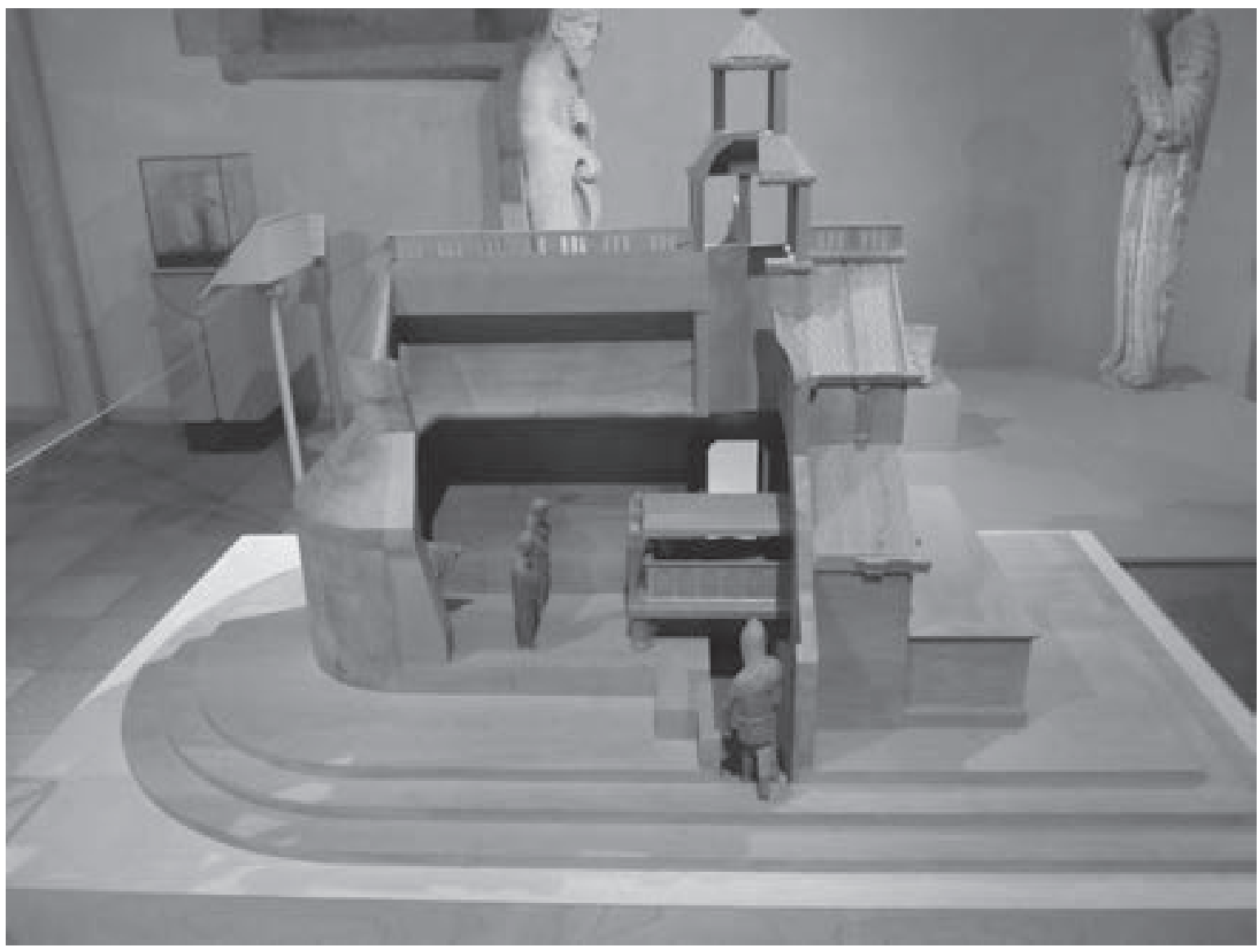

Fig. 4. Reconstruction of the free-standing monumental marble mausoleum containing the tomb of St Lazarus and a staging of his resurrection in the Church of St Lazarus in Autun. Autun: Musée Rolin. Photo by the author.

of the church (see above), as are Peter and Paul whose statues stand as the third and second from the left in the row of saints beside the window of the gable..$^{6}$

\section{Appropriation of an Appropriated Saint}

It has been suggested that the decoration of the west façade in I240-50, including a monumental statue of Mary Magdalene, must be seen in the light of the debate on the authenticity and possession of the relics of the saint..$^{57}$ In addition to the accounts that relate how the relics of Mary Magdalen came to Vézelay from Provence, the Vita apostolica beatae Mariae Magdalenae, a creation of Vézelay, explains how Mary Magdalene had arrived in Provence in the first place and, after a life of seclusion, was buried in Aix-en-
Provence.$^{8}$ A cult of Mary Magdalene existed in Provence since the beginning of the twelfth century and it seems that Vézelay was defeated by its own weapons when Aix-en-Provence claimed possession of the tombs containing the bodies of Mary Magdalene and Maximinus, the founders of the church of Aix. ${ }^{59}$ A charter of Archbishop Rostan de Fos (I056-82) which confirmed the possession of the tombs ('sepulcrum utriusque apud nos') was a forgery dating from the beginning of the thirteenth century when the claim was made. ${ }^{60}$

Whether or not forced by the claim made by Aix-en-Provence, in 1265 a ceremony for the verification of the relics of Mary Magdalene took place at Vézelay. ${ }^{61} \mathrm{~A}$ letter written by the bishops of Auxerre and Banias describes the ceremony on the night of the 4 October I265 


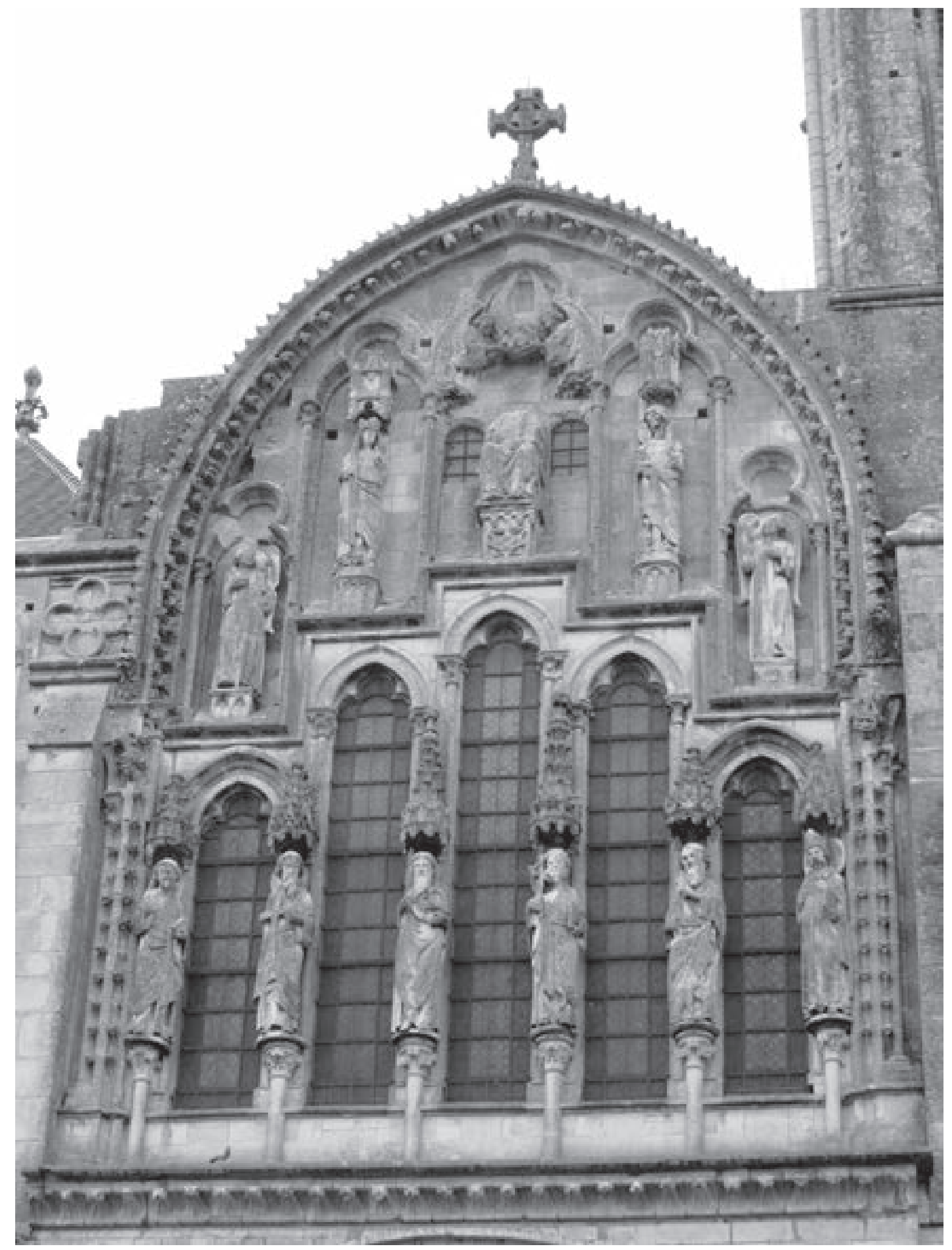

Fig. 5. Vézelay, Church of St Mary Magdalene, upper part of the façade with a statue of Mary Magdalene in the apex of the gable, to the right of the remains of the figure of Christ seated, , c. I240-50. Photo by the author. 


\section{Mariëtte Verhoeven}

at which both were present. It mentions that the ceremony took place at the location where, according to tradition, the relics were disposed, namely 'subtus magnum altare'. The reason for the verification is also given: so few relics were displayed in the church that some pilgrims questioned their presence. ${ }^{62}$ Then follows a description of the inventio during which a metallic box that contained human remains wrapped in two pieces of silk fabric was exhumed from underneath the main altar. The identification of the relics as being those of Mary Magdalene was corroborated by the find of a luxuriant female hair and a testimonial letter by King Charles. ${ }^{63}$

The inventio of 1265 was followed by a translatio of the relics during Easter 1267 in presence of King Louis IX and the papal legate Simon de Brion. ${ }^{64}$ In July of the same year Louis sent two precious reliquaries containing relics of Mary Magdalene, entrusted to him on the occasion of the translation, to the monastery of Vézelay. A letter from the king accompanying the reliquaries mentions that the relics consisted of an arm, a jaw and three teeth of the female saint. ${ }^{65}$ The arm was set in a piece of precious silverware in the form of a stretched arm with an opened hand, and the jaw and teeth in another piece that was pressed between the hands of a gilded angel. Moreover, in gratitude for donating to him a 'substantial portion' of the relics of Mary Magdalene, King Louis in return gave several relics from his own treasury, which partially derived from Constantinople and included a fragment of the True Cross, two thorns of the crown of thorns and various fragments of clothing of the Lord. These additional relics were placed in the hand of the arm reliquary.

Francis Salet supposed that during the inventio the relics were found in the confessio of the crypt underneath the main altar. After the inventio the tomb with fenestella (which according to Salet dated from the ninth century) was then placed in the church and transformed into an altar, while the relics were placed in the reliquaries donated by King Louis IX. ${ }^{66}$ The exact setting of the inventio and the locus of the relics, however, is not clear. The location, where ac- cording to tradition the relics were disposed, likely refers to the tomb of Mary Magdalene in the crypt. Both crypt and tomb, however, are not mentioned in the description of the ceremony. Instead we are told that a metal box containing the relics was exhumed from underneath the main altar. This probably refers to the confessio niche in the crypt, but it could also refer to a cavity or space in, or under, the main altar. ${ }^{67}$ The latter option would imply that at a certain point in time between II65 and I265 a (part of) the relics were translated to the upper floor of the church. Because the inventio was followed by a translatio, and because it is mentioned that so few relics were displayed in the church that some pilgrims questioned their presence, it is likely that with the translatio (a part of) the relics were visibly exhibited in the choir.

Despite the events of $1265-67$, the pilgrimage to Vézelay eventually came to a halt. It was, in the end, Saint-Maximin in Provence who succeeded in claiming the possession of the relics of Mary Magdalene after they found her body in one of the sarcophaguses in the crypt of the Church of St Maximin on 9 December I279. ${ }^{68}$ In I289, however, Pope Nicholas IV, confirmed the presence of the relics in Vézelay. ${ }^{69}$ Finally, to the cost of Vézelay, in I295 Pope Boniface VIII authenticated the invention of the relics at SaintMaximin. ${ }^{70}$

The written sources on the cult of Mary Magdalene in Vézelay attest that her relics rested in the Romanesque church on top of the hill, supposedly from the ninth century on. These same sources, however, also report that from the beginning there was doubt about the presence of the relics because of their origin, their small number, their limited visibility and the 'unworthy' setting in which they were presented. Neither does the material evidence point to a monumental manifestation of the 'much honoured tomb' that is mentioned in the pilgrim's guide to Santiago de Compostela. In the sculptural decoration of the church there were no references to Mary Magdalene except for a minor scene on the lintel of the tympanum and a statue in the apex of the gable of the façade, the latter from a rather late 


\section{Appropriation and Architecture}

date. Moreover, in the Middle Ages the church that is now known as 'La Madeleine' was not exclusively dedicated to the female saint. It seems that because the appropriation of Mary Magdalene was in the end not convincingly

\section{Notes}

I I would like to thank Sible for his guidance, collegiality and friendship. I especially cherish the memory of the excursions we made over the years to Rome, Ravenna, and Istanbul.

2 Mariëtte Verhoeven, The Early Christian Monuments of Ravenna: Transformations and Memory (Turnhout: Brepols, 20II), p. 73.

3 Liber Sancti Jacobi: The Pilgrim's Guide To Santiago de Compostela, transl. by William Melczer (New York: Italica, I993), pp. I04-05.

4 'GAUFRIDO abbati Vizeliacensis cenobii, quod est in honore domini nostri Iesu Christi et veneratione eiusdem genitricis et beatorum apostolorum Petri et Pauli, et beate MARIAE Magdalene, eiusque successoribus in perpetuum': Auxerre, Bibliothèque municipal, MS 227 (hereafter MS Auxerre 227), fol. 44 ; Monumenta vizeliacensia: Textes relatifs à l'histoire de l'abbaye de Vézelay, ed. by Robert B. C. Huygens, in Corpus Christianorum: Continuatio Mediaevalis (Turnhout: Brepols, I966-), XLII (I976), p. 29I.

5 'Abbatiam Viziliacensem, ubi sancta Maria Magdelene requiescit', in Patrologia latina, ed. by Jacques-Paul Migne (Paris: Migne, I844-55), CXLIII, col. 883.

6 Victor Saxer, 'Miracula Beate Marie Magdalene Vizeliaci facta. Étude de la tradition manuscrite des Recueils de miracles de la Madeleine à Vézelay', Bulletin Philologique et Historique (jusqu'à 1610) (I959), 69-82; Etienne Michel Faillon, Monuments inédits sur l'apostolat de Sainte Marie-Madeleine en Provence, ed. by Jacques-Paul Migne, 2 vols (Paris: Migne, I865), II, col. 737: 'Ipse vero statim, arrepto intenre, nudis gressibus deveniens ad monasterium Viceliaci, grates redditurus pro sua liberatione, ferens secum compedes jam innoxias, atque ante tumulum beatae Mariae suspendit'. Saxer dates the manuscript (Paris, MS lat. 5296 B) on which Faillon based his text edition to the thirteenth century: Saxer, 'Miracula', p. 72.

7 Manuscripts belonging to Group D, twelfth-fourteenth century, as classified in Saxer, 'Miracula', pp. 75-76; Faillon, II, col. 739: 'Quos assumens praedictus abbas fabris contulit, ac in giro altaris redas ferreas exinde fieri iussit'

8 The Book of Sainte Foy, transl. by Pamela Sheingorn (Philadelphia: University of Pennsylvania Press, I995), p. I7.

9 Melczer, p. Iо6.

Io Ibid., pp. IIо, II6. delivered, Provence could successfully claim the possession of the whole body of the saint and Vézelay, in its turn, could not keep the memory of the presence of the relics of Mary Magdalene alive.

I I 'Leonard', in Kunera: Database of Medieval Badges and Ampullae, Radboud University Nijmegen $<$ http://www.kunera.nl $>$ [accessed I4 April 2016].

I2 Rosalind K. Berlow, 'Social and Economic Aspects of the Early History of Vézelay (Ninth to Twelfth Centuries)' (unpublished doctoral thesis, City University of New York, I97I), pp. 93-Ioo.

I3 Because the miracle accounts give no explanation for how the relics came to Vézelay, Victor Saxer concluded that they must be of an earlier date (c. I037-43) than the sources that do so and which according to Saxer date from around the middle of the eleventh century: Victor Saxer, Le Culte de Marie Madeleine en Occident des origines à la fin du moyen âge (Auxerre: Publications de la Société des Fouilles Archéologiques et des Monuments Historiques de l'Yonne; Paris: Librairie Clavreuil, I959), p. 7. Berlow, p. 93, dates the miracle accounts shortly after I040.

I4 Saxer, Le culte, pp. 60-65.

I5 Faillon, II, col. 739: 'Nam cuncator a multis qualiter fieri potuit ut corpus baetae Mariae Magdalenae, cuius exortus in Judea fuit, de tam longinquae regione ad Gallarum partes delatum sit. Sed his paucis respondendum, quoniam omnia possibilia sunt apud Deum, et quaecumque voluit fecit'. This text passage appears in manuscripts belonging to Group B and $\mathrm{D}$ as classified in Saxer, 'Miracula', pp. 72-76. Saxer dates the oldest manuscript I070, which seems contradictory to the dating of the miracle accounts in c. I037-43 (see above, n. I3).

I6 Victor Saxer, Le dossier Vézelien de Marie Madeleine: Invention et translation des reliques en 1265-1267 (Brussels: Société des Bollandistes, I975), p. 77; dated I04I-43.

I7 Saxer, Le dossier Vézelien, p. 77.

I8 Bibliotheca Hagiographica Latina (hereafter BHL) 5442, 5488; Faillon, II, cols 573-74, 74I-44; Saxer, Le dossier Vézelien, p. 78 .

I9 BHL, 549I; Saxer, Le dossier Vézelien, no. 2: 'Incipit Legenda Translationis Gloriose Marie Magdalene [...]', pp. 236-4I; Hugh of Poitiers: The Vézelay Chronicle, transl. by John Scott and John O. Ward (Binghamton, NY: Center for Medieval and Early Renaissance Studies, I992), Appendix D, 'The Little Book of Vézelay about the Relics and Translation of the Blessed Mary Magdalene', pp. 336-4I.

20 Charter I, MS Auxerre 227, fol. $23^{\mathrm{r}}$, ed. Huygens, p. 246: 'Pari etiam ordine fundavimus aliud monasterium...in honore domini nostri Iesu Christi, in loco vel agro, qui dicitur Vizeliacus [...]. For the dating in 


\section{Mariëtte Verhoeven}

858-59, see M. René Louis, Girart, comte de Vienne et ses fondations monastiques (Auxerre: Imprimerie Moderne, I946). I, fol. $23^{\mathrm{r}}$, ed. Huygens, p. 246; dedication to Jesus Christ and the Virgin Mary: MS Auxerre 227, charter 2, fol. $26^{\mathrm{r}}$, ed. Huygens, p. 249; dedication to Jesus Christ, the Virgin Mary and Peter and Paul: Berlow, p. 85 , n. I4I, referring to Catalogus codicum latinorum Bibliothecae Laurentianae, ed. by Angelo Maria Bandini (Florence, I774), col. I34, which I could not consult myself.

23 Translatio SS. Eusebii et Pontiani, Analecta Bollandiana, 2 (1883), pp. 368-77.

24 The first mention of Andeolus in relation to Vézelay dates from 878 when Charles the Bald re-confirmed the privileges of the monastery 'in honour of our Lord Jesus Christ and of his mother the Virgin Mary and also of St Peter and St Andeolus, martyrs'. In 900 Horolfus granted his gifts 'to our Lord Saviour and his mother the Blessed Mary in the monastery called Vézelay where rest the bodies of the Blessed Martyrs, namely Andeolus and Pontianus', see Berlow, p. 85 and nn. I42 and I44, referring to Bandini, cols I34 and I33. In Acta Sanctorum, Tomus V, augusti (Antwerp I74I), p. II3, n. I3, it is mentioned that a monk from Auxerre mentioned in his Chronologia under the year 856 that Gerard de Rousillon acquired the relics of Eusebius and Pontianus from Pope Nicholas in Rome and transferred them to Gallia; the relics of Eusebius to his monastery in Pothières and those of Pontianus to his monastery in Vézelay.

25 Patrick J. Geary, Furta Sacra: Thefts of Relics in the Central Middle Ages, rev. edn (Princeton, NJ: Princeton University Press, I990), pp. 58-63 and p. 78.

26 MS Auxerre 227, fol. I4 ', ed. Huygens, p. 224: 'Dedicatio ecclesie Vizeliaci ab abbate Artaldo edificate'; Francis Salet, La Madeleine de Vézelay (Melun: Librairie d'Argences, I948), p. 23.

27 Miracula S. Mariae Magdalenae [Vizeliacensis], Analecta Bollandiana, I7 (I898), pp. I77-79. Dating by Salet, La Madeleine, p. 88.

28 Salet, La Madeleine, p. 87.

29 Christian Sapin, 'La crypte de Vézelay (Yonne): quelle place pour les reliques de Marie-Madeleine et la statue dela Vierge ? L'apport de l'archéologie du bâti et des sources textuelles', Bulletin du centre d'études médiévales d'Auxerre, I9, I (20I5), I-IO, http://cem.revues.org/I3945.

30 Sapin, 'La crypte de Vézelay', p. 3.

3I Ibid., p. 3; Christian Sapin, Les cryptes en France (Paris: Picard, 2014), pp. I32, I34.

32 See above, n. I9.

33 According to Saxer, Le dossier Vézelien, p. 78, the description of the sarcophagus proofs that the narrator envisaged one of the sarcophaguses in the crypt of Saint-Maximin in Provence. This seems contradic- tory to Saxer's statement that the attribution of one of the sarcophaguses to Mary Magdalene cannot be attested before the thirteenth century: Saxer, Le culte, pp. 46-47. It also would imply that the translation report is an eyewitness account, which is highly unlikely.

34 MS Auxerre 227, fol. I4 , ed. Huygens, p. 223.

35 'ecclesiam peregrinorum': MS Auxerre 227, fols $69^{\mathrm{r}}$, $70^{\mathrm{r}}, 7 \mathrm{I}^{\mathrm{r}}$, ed. Huygens, pp. 403, 405, 406. It is not clear if the 'Church of the Pilgrims' referred to an independent structure, the entire church or, less probably, the narthex. See also Berlow, pp. I65-66.

36 Salet, La Madeleine, p. 25.

37 Arnaud Timbert, Le chevet de la Madeleine de Vézelay et le premier gothique bourguignon (Rennes: Presses Universitaires de Rennes, 2009).

38 MS Auxerre 227, fol. I6 ${ }^{\mathrm{r}}$, ed. Huygens, p. 566; transl. by Scott and Ward, pp. 284-85.

39 John Crook, The Architectural Setting of the Cult of Saints in the Early Christian West c. 300-1200 (Oxford: Oxford University Press, 2000), pp. I33-34, suggested that the term crypta, used for the vault above the tomb, referred to the main apse of the church and that therefore the relics were elevated to the choir by the mid-twelfth century.

40 Sapin, 'La crypte de Vézelay', p. 7.

4I Salet, La Madeleine, pp. 88-89.

42 Sapin, 'La crypte de Vézelay', p. 7.

43 Lydwine Saulnier and Neil Stratford, La sculpture oubliée de Vézelay, Bibliothèque de la Société Française d'Archeologie, I7 (Paris: Arts et Métier graphiques, I984), pp. I7I-72, I77-78 and Figs I82-84; Le Patrimoine de la Basilique de Vézelay, ed. by Muriel Vandeventer and others (Charenton-le-Pont: Flohic Éditions, I999), p. I23.

44 I want to thank Paul le Blanc for pointing out these fragments to me when he showed me around in Vézelay.

45 Le Patrimoine, p. I23.

46 Sapin, 'La crypte de Vézelay', p. 3; Sapin, Les Cryptes en France, p. 2 I 2.

47 The current stairs date from the time of the restoration of the church around the middle of the nineteenth century under Viollet-le-Duc. On both sides the lower part of the twelfth-century stair is still visible. Before Viollet-le-Duc's restoration there existed a stair in the third southern bay that possibly dated from the thirteenth century and that probably gave access to the crypt during the building activities: Sapin, 'La crypte de Vézelay', p. 2 and n. 3.

48 Sapin, Les cryptes en France, p. II9.

49 Ibid., p. II9; according to Kees van der Ploeg, 'Preserving and Reshaping: The Intricacies of Liturgy and Architecture at St. Lebuinus', Deventer', in Unitas in Pluralitate: Libri Ordinarii als Quelle für die Kulturgeschichte. Libri Ordinarii as a Source for Cultural History, ed. by Charles Caspers and Louis van Tongeren (Münster: Aschendorff, 20I5), p. I89 and n. 2I, Abbot 
Suger preserved the crypt which became a relic in its own right. Christian Sapin, Les cryptes en France, p. 209, points out that crypts in the later Middle Ages gradually lost their religious function and became lieux de mémoire.

50 Sapin, Les cryptes en France, pp. 2I0-II; Linda Seidel, Legends in Limestone: Lazarus, Gislebertus, and the Cathedral of Autun (Chicago: University of Chicago Press, 1999), pp. 40-43. Seidel (Fig. 22) shows the ground plan of the mausoleum traced on the church's floor as it appeared in 1998.

5I I thank Paul le Blanc for pointing out this example to me. The text on the elevation has survived in a eighteenth-century manuscript now in the Archives Départementales de la Côte d'Or, G 3I45, chapitre Saint-Andoch (I7I6-36), fols $9 \mathrm{I}^{\mathrm{v}}-94^{\mathrm{v}}$. See also Laurent Durnecker, Saulieu: Les corps saints à Saulieu du tombeau aux reliquaires (VI ${ }^{e}-X V I I I^{e}$ S.) (Saulieu: Association des Amis du Vieux Saulieu, 2002), pp. I6-I7; Francis Salet, 'La basilique Saint-Andoche de Saulieu', in Congrès archéologique de France, Auxois-Châtillonnais (Paris : Société française d'archéologie, I986), pp. 235-43.

52 I do not follow the argument of Crook, see above n. 39 .

53 Salet, La Madeleine, pp. I73-20I; Le Patrimoine, pp. 38-I46 ; Kirk Ambrose, The Nave Sculpture of V'́zelay: The Art of Monastic Viewing (Toronto: Pontifical Institute of Mediaeval Studies, 2006).

54 Saulnier and Stratford, p. 246 and Figs 28-29; Le Patrimoine, p. I26. Currently the fragments of the tympanum and lintel have been removed for restoration.
Saulnier and Stratford, p. 9 and n. 45 .

BHL 5443-5449; Guy Lobrichon, 'Le dossier Magdalénien aux $\mathrm{XI}^{\mathrm{e}}-\mathrm{XII}^{\mathrm{e}}$ siècles', Mélanges de l'Ecole française de Rome: Moyen-Age, Temps modernes, $\mathrm{IO}_{4}$ (1992), I63-80. Lobrichon dates this source in the second half of the eleventh century. See also Geary, p. 76.

59 Saxer, Le culte, pp. 95-96.

60 Ibid., pp. I03-07.

6I Saxer, Le dossier Vézelien, no. 9, pp. 260-62.

62 Ibid., p. 260, lines I4-I6: 'verum quia de reliquiis ipsius parum peregrinantibus exhibebatur, a nonnullis extitit hesiatatum'

63 Ibid., p. 98.

64 Ibid., pp. IO3-I2, 263-68.

65 Ibid., pp. I08-I2, 264-66.

66 Salet, La Madeleine, pp. 29, 89.

67 According to Saxer, Le dossier Vézelien, p. 98, the relics were put back 'dans la fosse d'où on l'avait extrait'. See 'Der Kastenaltar', in Joseph Braun, Der christliche Altar in seiner geschichtlichen Entwicklung, 2 vols (Munich: Alte Meister Günther Koch, I924), I, pp. I9I-2II.

68 Saxer, Le culte, pp. 230-33.

69 Saxer, Le dossier Vézelien, pp. 87, 256: 'ut ecclesie monasterii vetri, in qua corpus beate Marie Magdalene, cuius est insignita vocabulo, requiescit [...]'.

70 Ibid., p. I65. 
